\title{
Optimization of flat-oval pipes and perspectives of their application in core structures
}

\author{
Alexander Marutyan ${ }^{1}$, Tamazi Kobaliya ${ }^{2}$ and Evgeny Galdin ${ }^{3}$ \\ ${ }^{1}$ Department of Project Grant Organization, Institute of Service, Tourism and Design (branch) of \\ North Caucasus Federal University in Pyatigorsk, 357500, Pyatigorsk, St. 40 let Octyabrya, 56, \\ Russia. \\ ${ }^{2 " C o n s t r u c t i o n " ~ D e p a r t m e n t, ~ I n s t i t u t e ~ o f ~ S e r v i c e, ~ T o u r i s m ~ a n d ~ D e s i g n ~(b r a n c h) ~ o f ~ N o r t h ~ C a u c a s u s ~}$ \\ Federal University in Pyatigorsk, 357500, Pyatigorsk, St. 40 let Octyabrya, 56, Russia. \\ 3"Design" Department, Institute of Service, Tourism and Design (branch) of North Caucasus Federal \\ University in Pyatigorsk, 357500, Pyatigorsk, St. 40 let Octyabrya, 56, Russia.
}

\begin{abstract}
The calculation of optimal parameters of flat-oval pipes is given by an approximate method, the correctness of which is confirmed by testing using standardized profiles. A new layout of gratings made of flatoval shaped pipes is presented, developed for truss systems based on steel rod structures of coatings with replacement of bar-shaped bent elements with tubular ones. The caseless junctions of belts and lattices with direct joining of rod elements to each other without alignment are developed, as well as with structural eccentricities limited to 0.25 of the height of the waist elements, which allows not to take them into account in calculations and provides an increase in the degree of unification of the nodes of the upper and lower belts of carrier's constructions. The prospects of using a new technical solution in light metal structures of buildings and structures are shown. The area of its rational application is outlined, where by means of variant design of typical, known and new solutions, a quantitative estimate of the reduction in the consumption of structural material is given. The whole diagram of changes in the design parameters of flat-oval pipes is shown in the transformation of their cross-sections from vertical configurations to horizontal ones, including the transition through the outline of a circular shape.
\end{abstract}

\section{Introduction}

In search of new technical solutions for light steel structures of buildings and structures in general [1], as well as their hinged-rod and cross (truss) systems in particular (Fig. 1) [2] it is very attractive and useful to take as a basis long-term practice of steel rod structures coatings [3], replacing zigzag grids from rods with similarly shaped grids from profile pipes. 


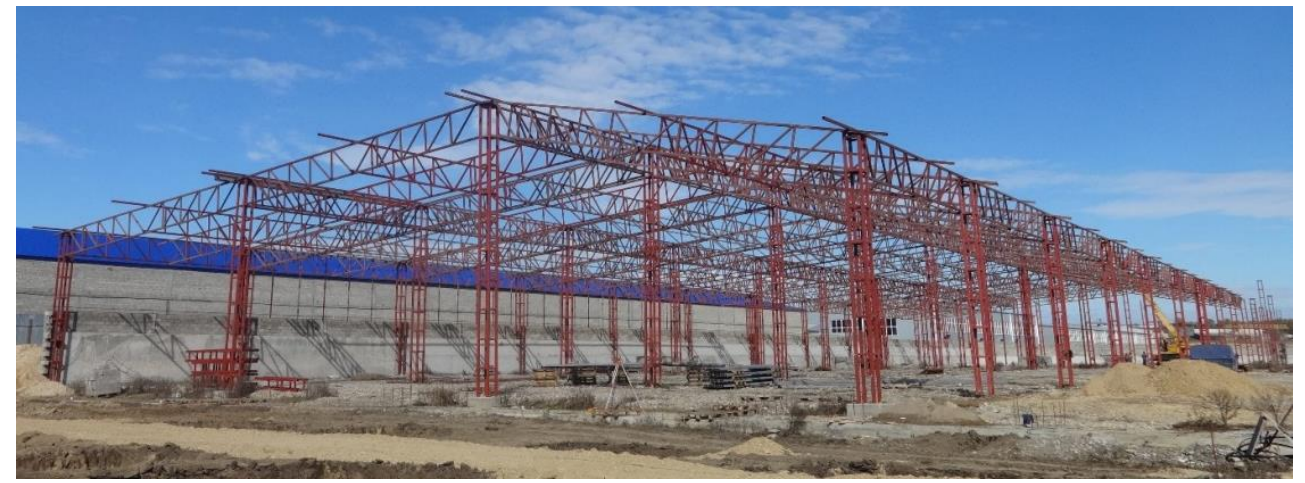

a)

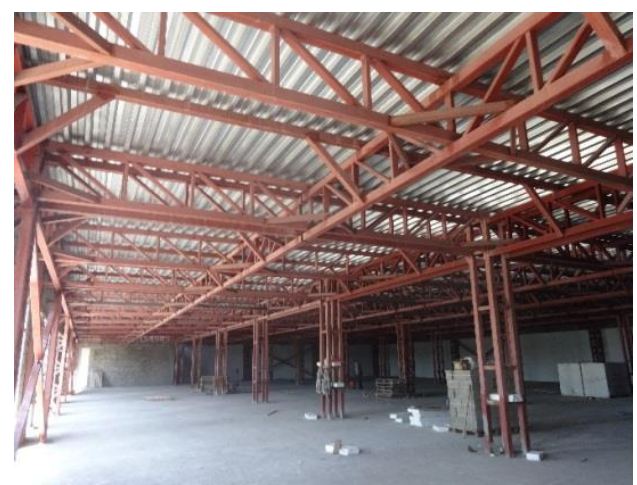

b)

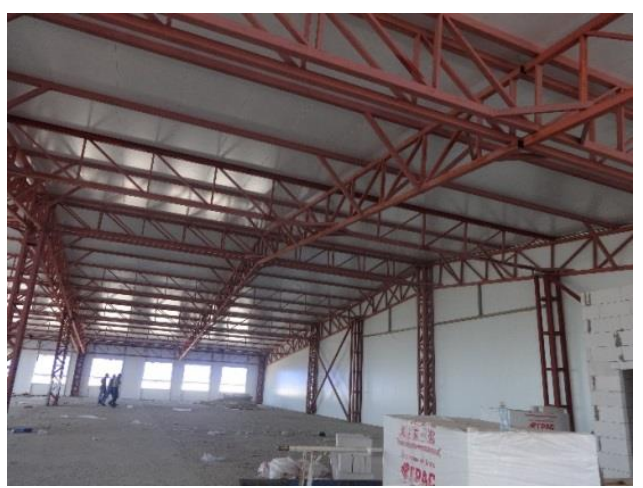

c)

Fig. 1. Pictures of the frame from rectangular pipes with mounting windows in the initial stage of construction (a), as well as blocks of overlap (b) and coating (c) from cross-farms of the "Pyatigorsk" type during finishing works.

Thus, in the case of run-free coatings, a new structural and layout solution has been developed for trusses with similar lattices of flat-oval pipes, in which the cross-sectional dimensions differ by a ratio of $1 / 2,63$ [4], where the larger dimension is located in the plane of the lattice, and the smaller one - from the plane (Fig.2).

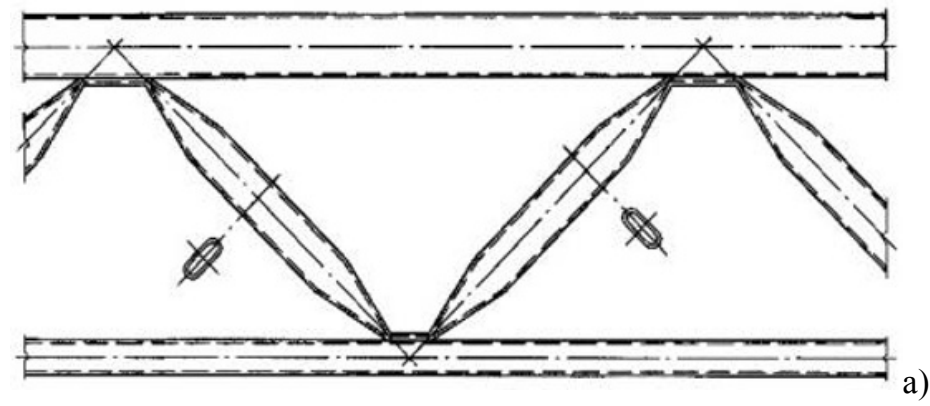



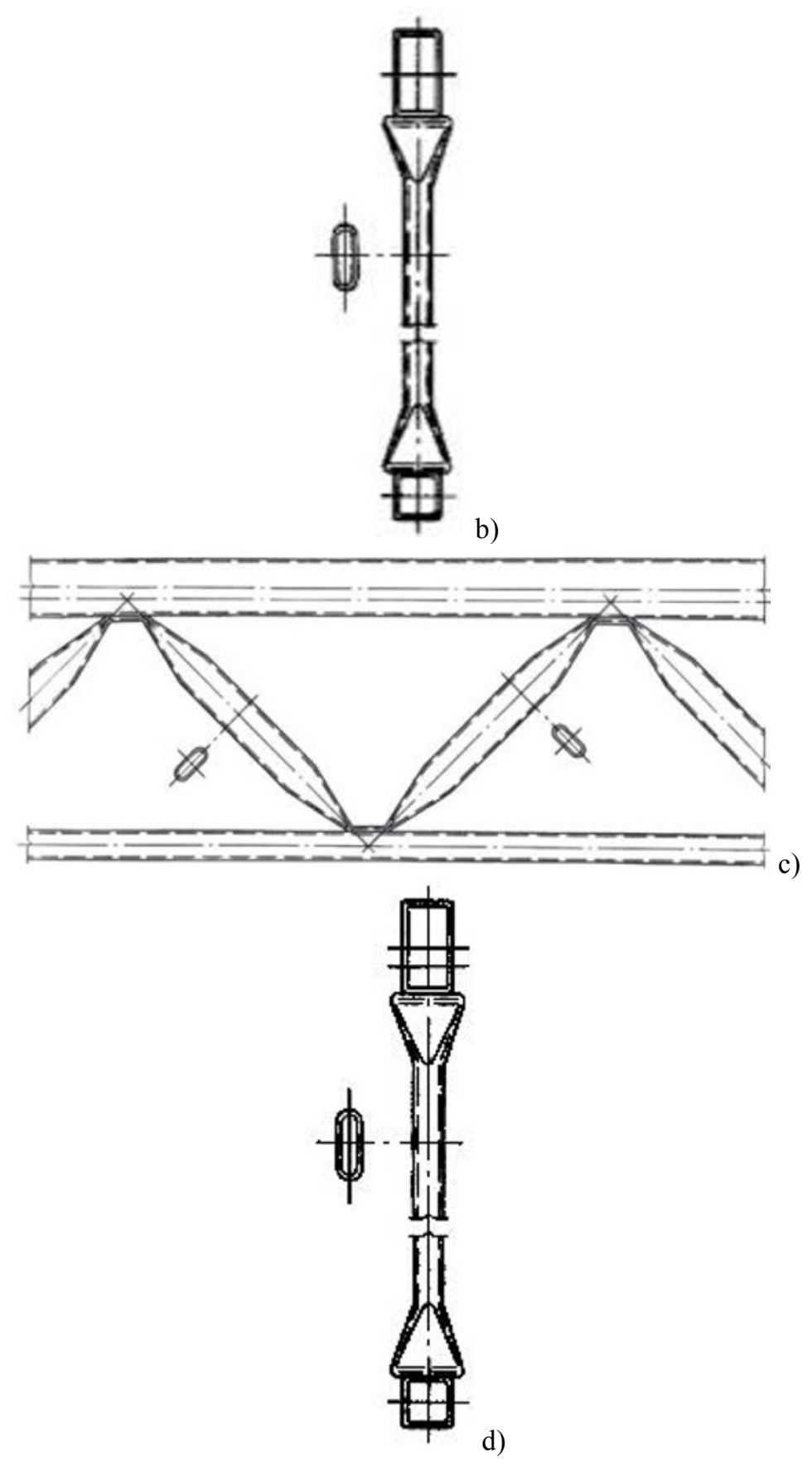

d)

Fig. 2. Schemes of trusses with lattices of flat-oval pipes: a - side view of the fragment; $b$ - cross section; $\mathrm{c}$ - side view of the fragment with unified nodes; $d$ - cross-section with unified nodes

\section{Methods}

For abutting to the belts and forming gussetless nodes flat-oval profile in the projected places flattened and double bends give a zigzag appearance. In comparison with rod 
elements, such grids have a higher load-bearing capacity (especially when compressed), which allows increasing the load on the structure or, at a fixed load, to reduce its metal consumption. The flattening and double bending of the tubular elements of the grids form gussetless nodes without structural eccentricities, characteristic of trusses and trunks of rectangular pipes. However, in order to increase the degree of unification of the nodes of the upper and lower belts, it is quite justified to use constructive eccentricities limited to 0.25 of the height of the belt elements, which allows them not to be taken into account in calculations [5]. Flattening also protects the wall of the belt elements from the pushing and allows to reduce its thickness. On the lines of bends in the plane of the construction sheet hinges are formed, which not only correspond to the hinge-rod calculation scheme (model), but also bring it closer to the real object [6]. From the plane of the structure, the same bends of flattened sections of the flat-oval profile have the greatest rigidity, approximating the rigidity of the frame fastening, due to which the bonding elements in the supporting structures can be reduced. With hinged fixations in the planes of structures and rigid (frame) planes, the calculated lengths of the rod elements of the grids in the planes of the structures are twice the calculated lengths from the planes [7]. Therefore, in order that the rod elements of the grids in both directions have equal flexibility, it is expedient to use profiles in which the radii of inertia of the section along the main central axes also differ by a factor of two. The thin-walled sections of a flat-oval shape with a ratio of dimensions $1 /$ 2,63 , where large dimensions are located in the planes of structures, and smaller ones from planes, fully correspond to the indicated condition. Profiles with this ratio differ from flatoval pipes from standard grades.

To derive the above ratio and quantify the load-bearing capacity, it is expedient to calculate the static (geometric) characteristics of the section of the flat-oval pipe (Fig. 3, a). This section is a figure that includes two rectangles and two semi rings, each of which is a sector of a thin-walled ring with an angular parameter $\alpha=90^{\circ}=\pi / 2=1,57$ (Fig. 3, b) (Fig. 3, b) [8]:

$y_{c}=R \sin \alpha / \alpha=R \times 1 / 1,57=0,6369426 R=0,6369426 \times 0,5 U=0,3185 U ;$

$I_{x}=\left(2 \alpha+\sin 2 \alpha-4(\sin \alpha)^{2} / \alpha\right) R^{3} t / 2=(3,14+0-4 / 1,57) R^{3} t / 2=$

$=0,2961146(0,5 U)^{3} t=0,0370143 U^{3} t$

$I_{y}=(2 \alpha-\sin 2 \alpha) R^{3} t / 2=(3,14-0) R^{3} t / 2=1,57(0,5 U)^{3} t=0,196250 U^{3} t$

$$
A=2 \alpha R t=2 \times 1,57 \times 0,5 U t=1,57 U t,
$$




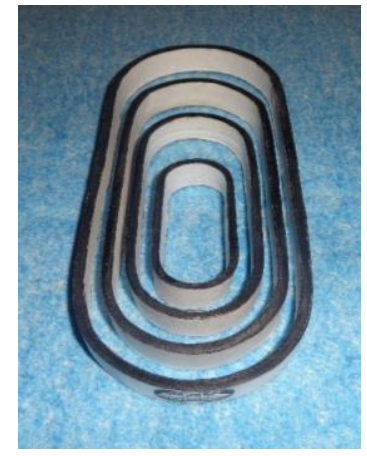

a)

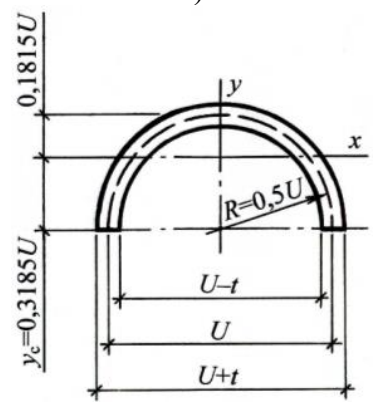

b)

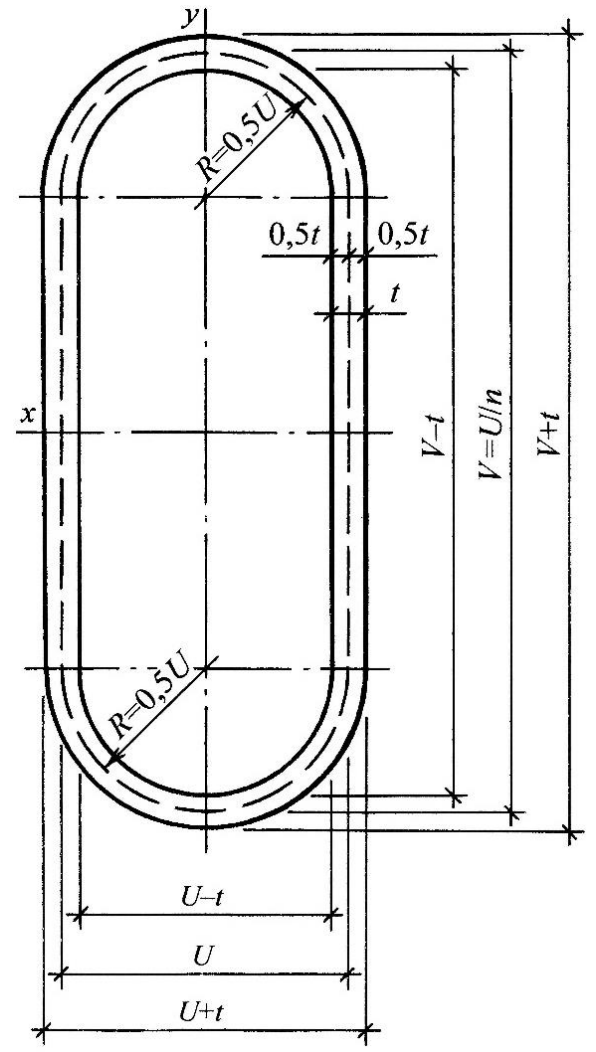

c)

Fig. 3 A snapshot of the shear of different-sized flat-oval pipes (a) and the design cross-sections of one of the two curvilinear sections having the shape of round semi rings (b), as well as the composite section of the flatoval pipe (c)

Where $y_{c}, I_{x}, I_{y}, A$ - the ordinate of the center of gravity, the moments of inertia relative to the axes $x-x, y-y$, respectively, the cross-sectional area of the semi ring; $\mathrm{R}$ - the radius of the semi ring around its midline, $R=0,5 U ; U, V$-respectively, smaller, larger dimensions of the cross-section of the flat-oval pipe along the middle line; $n$-ratio of dimensions (smaller to larger), $n=U / V ; t$ - wall thickness of the flat-oval tube.

To calculate the moments of inertia of the section of the flat-oval pipe, one can apply parallel displacement of the axes, substituting $V=U / n$ :

$$
\begin{aligned}
& I_{x}=2\left(0,037014 \mathrm{~J}^{3} t+1,57 U t(U(0,5 / n-0,5)+0,3185)^{2}+8 U^{3}(0,5 / n-0,5)^{3} t / 12\right)= \\
& =U^{3} t\left(0,0740286+0,785(1 / n-0,363)^{2}+(1 / n-1)^{3} / 6\right) \\
& \mathrm{I}_{\mathrm{y}}=2\left(0,196250 \mathrm{U}^{3} \mathrm{t}+2 \mathrm{U}(0,5 / \mathrm{n}-0,5) \mathrm{t}^{3} / 12+2 \mathrm{U}(0,5 / \mathrm{n}-0,5) \mathrm{t}(\mathrm{U} / 2)^{2}\right)= \\
& =\mathrm{U}^{3} \mathrm{t}(0,5 / \mathrm{n}-0,1075)+0,1667 \mathrm{Ut}^{3}(1 / \mathrm{n}-1) \approx \mathrm{U}^{3} \mathrm{t}(0,5 / \mathrm{n}-0,1075)+0= \\
& =\mathrm{U}^{3} \mathrm{t}(0,5 / \mathrm{n}-0,1075)
\end{aligned}
$$


The cross-sectional area is quite acceptable to calculate by the length of the middle line:

$$
A=t(\pi U+2(U / n-U))=t(3,14 U+2 U(1 / n-1))=U t(2 / n+1,14) .
$$

All calculations must be tested, since they are made along the middle line and at the same time in the formula (6) the term of an extremely insignificant quantity is excluded because of the thickness parameter contained in it, raised to the third power $\left(t^{3}\right)$. Testing is advisable on the basis of the 12 most large-caliber and thick-walled flat-oval pipes type A in accordance with GOST R 54157-2010 [9]. According to its main results (Table 1), we can conclude that the formulas obtained are sufficiently correct.

Table 1. Calculation parameters of geometrical characteristics of cross-sections of flat-oval pipes

\begin{tabular}{|c|c|c|c|c|c|c|c|c|c|c|c|}
\hline \multirow[b]{2}{*}{$\begin{array}{c}\text { Cross } \\
\text { sections, } \\
\mathrm{mm}\end{array}$} & \multicolumn{5}{|c|}{ Profile settings } & \multicolumn{3}{|c|}{ By GOST R 54157-2010 } & \multicolumn{3}{|c|}{ By calculation } \\
\hline & $U, \mathrm{~mm}$ & $\underset{\mathrm{mm}}{V,}$ & $\begin{array}{l}n= \\
U / V\end{array}$ & $t / U$ & $t / V$ & $\begin{array}{c}A \\
\mathrm{~cm}^{2} \\
\%\end{array}$ & $\begin{array}{c}I_{x}, \\
\mathrm{~cm}^{4} \\
\%\end{array}$ & $\begin{array}{c}I_{y}, \mathrm{~cm}^{4} \\
\%\end{array}$ & $\begin{array}{c}A, \\
\mathrm{~cm}^{2} \\
\%\end{array}$ & $\begin{array}{c}I_{x}, \mathrm{~cm}^{4} \\
\%\end{array}$ & $\begin{array}{c}I_{y}, \\
\mathrm{~cm}^{4} \\
\%\end{array}$ \\
\hline $42 \times 26,5 \times 5$ & 21,5 & 37 & $\begin{array}{c}1 / \\
1721\end{array}$ & $\begin{array}{c}1 / \\
4.3\end{array}$ & $\begin{array}{c}1 / \\
7.4\end{array}$ & $\begin{array}{r}4,93 \\
100\end{array}$ & $\begin{array}{l}8,04 \\
100\end{array}$ & $\begin{array}{c}3,88 \\
100\end{array}$ & $\begin{array}{c}4,9254 \\
99,91\end{array}$ & $\begin{array}{c}7,8711 \\
97.90\end{array}$ & $\begin{array}{c}3,7416 \\
96,43\end{array}$ \\
\hline $46 \times 30 \times 6$ & 24 & 40 & $\begin{array}{c}1 / \\
1,667\end{array}$ & $\begin{array}{l}1 / \\
4\end{array}$ & $\begin{array}{l}1 / \\
5\end{array}$ & $\begin{array}{c}6,44 \\
100\end{array}$ & $\begin{array}{l}12,4 \\
100\end{array}$ & $\begin{array}{c}6,28 \\
100\end{array}$ & $\begin{array}{l}6,4416 \\
100,03\end{array}$ & $\begin{array}{c}12,089 \\
97,50\end{array}$ & $\begin{array}{c}6,0204 \\
95,87 \\
\end{array}$ \\
\hline $60 \times 20 \times 1$ & 19 & 59 & $\begin{array}{c}1 / \\
3,105\end{array}$ & $\begin{array}{l}1 / \\
19\end{array}$ & $\begin{array}{l}1 / \\
59\end{array}$ & $\begin{array}{l}1,40 \\
100\end{array}$ & $\begin{array}{l}5,17 \\
100\end{array}$ & $\begin{array}{c}0,993 \\
100\end{array}$ & $\begin{array}{c}1,3966 \\
99,76\end{array}$ & \begin{tabular}{|c|}
5,1665 \\
99,93 \\
\end{tabular} & $\begin{array}{c}0,9912 \\
98,82\end{array}$ \\
\hline $60 \times 20 \times 1,5$ & 18,5 & 58,5 & $\begin{array}{c}1 / \\
3,162\end{array}$ & $\begin{array}{c}1 / \\
12,3\end{array}$ & $\begin{array}{l}1 / \\
39\end{array}$ & $\begin{array}{l}2,07 \\
100\end{array}$ & $\begin{array}{l}7,52 \\
100\end{array}$ & $\begin{array}{l}1,4 \\
100\end{array}$ & $\begin{array}{l}2,0713 \\
100,07\end{array}$ & $\begin{array}{c}7,5119 \\
99,89\end{array}$ & $\begin{array}{l}1,3995 \\
99,97\end{array}$ \\
\hline $60 \times 20 \times 2$ & 18 & 58 & $\begin{array}{c}1 / \\
3,222\end{array}$ & $\begin{array}{l}1 / \\
9\end{array}$ & $\begin{array}{l}1 / \\
29\end{array}$ & $\begin{array}{c}2,73 \\
100\end{array}$ & $\begin{array}{c}0,72 \\
100\end{array}$ & $\begin{array}{l}1,77 \\
100\end{array}$ & $\begin{array}{l}2,7304 \\
100,02\end{array}$ & $\begin{array}{c}9,7050 \\
99,85\end{array}$ & $\begin{array}{c}1,7538 \\
99,09\end{array}$ \\
\hline $63 \times 9 \times 1$ & 8 & 62 & $\begin{array}{c}1 / \\
7,750\end{array}$ & $\begin{array}{l}1 / \\
8\end{array}$ & $\begin{array}{l}1 / \\
62\end{array}$ & $\begin{array}{c}1,33 \\
100\end{array}$ & $\begin{array}{l}100 \\
4,82 \\
100\end{array}$ & $\begin{array}{c}0,194 \\
100\end{array}$ & $\begin{array}{l}1,3312 \\
100,09\end{array}$ & $\begin{array}{l}4,8214 \\
100,03\end{array}$ & $\begin{array}{c}0,1929 \\
99,43\end{array}$ \\
\hline $65 \times 32 \times 1$ & 31 & 64 & $\begin{array}{c}1 / \\
2,065\end{array}$ & $\begin{array}{l}1 / \\
31\end{array}$ & $\begin{array}{l}1 / \\
64\end{array}$ & $\begin{array}{l}1,63 \\
100\end{array}$ & $\begin{array}{l}7,59 \\
100\end{array}$ & $\begin{array}{l}2,76 \\
100\end{array}$ & $\begin{array}{l}1,6334 \\
100,21\end{array}$ & $\begin{array}{c}7,5901 \\
100,0\end{array}$ & $\begin{array}{c}2,7549 \\
99,82\end{array}$ \\
\hline $65 \times 32 \times 1,5$ & 30,5 & 63,5 & $\begin{array}{c}1 / \\
2,082\end{array}$ & $\begin{array}{c}1 / \\
20,3\end{array}$ & $\begin{array}{c}1 / \\
42,3\end{array}$ & $\begin{array}{c}2,43 \\
100\end{array}$ & $\begin{array}{c}11,09 \\
100\end{array}$ & $\begin{array}{l}3,98 \\
100\end{array}$ & $\begin{array}{c}2,4266 \\
99,86\end{array}$ & $\begin{array}{c}11,085 \\
99,96\end{array}$ & $\begin{array}{c}3,9728 \\
99,82\end{array}$ \\
\hline $65 \times 32 \times 2$ & 30 & 63 & $\begin{array}{c}1 / \\
2,100\end{array}$ & $\begin{array}{c}c 0,5 \\
1 / \\
15\end{array}$ & $\begin{array}{c}1 / \\
31,5\end{array}$ & $\begin{array}{l}3,2 \\
100\end{array}$ & $\begin{array}{l}14,4 \\
100\end{array}$ & $\begin{array}{l}5,10 \\
100\end{array}$ & $\begin{array}{l}3,2040 \\
100,13\end{array}$ & $\begin{array}{c}14,387 \\
99,91\end{array}$ & $\begin{array}{c}, 0896 \\
99,79\end{array}$ \\
\hline $70 \times 36 \times 1$ & 35 & 69 & $\begin{array}{c}1 / \\
1,971\end{array}$ & $\begin{array}{l}1 / \\
35\end{array}$ & $\begin{array}{l}1 / \\
69\end{array}$ & $\begin{array}{l}1,78 \\
100\end{array}$ & $\begin{array}{c}9,68 \\
100\end{array}$ & $\begin{array}{l}3,77 \\
100\end{array}$ & $\begin{array}{l}1,7790 \\
99,94\end{array}$ & $\begin{array}{l}9,6796 \\
99,996\end{array}$ & $\begin{array}{c}3,7653 \\
99,86\end{array}$ \\
\hline $70 \times 36 \times 1,5$ & 34,5 & 68,5 & $\begin{array}{c}1 / \\
2,986\end{array}$ & $\begin{array}{l}1 / \\
23\end{array}$ & $\begin{array}{c}1 \\
/ 45,7\end{array}$ & $\begin{array}{l}2,65 \\
100\end{array}$ & $\begin{array}{c}14,18 \\
100\end{array}$ & $\begin{array}{l}5,46 \\
100\end{array}$ & $\begin{array}{c}2,6450 \\
99,81\end{array}$ & $\begin{array}{c}14,167 \\
99,91\end{array}$ & $\begin{array}{c}5,4528 \\
99,87\end{array}$ \\
\hline $70 \times 36 \times 2$ & 34 & 68 & $\begin{array}{l}1 / \\
2\end{array}$ & $\begin{array}{l}1 / \\
17\end{array}$ & $\begin{array}{l}1 / \\
32\end{array}$ & $\begin{array}{l}3,5 \\
100\end{array}$ & $\begin{array}{c}18,45 \\
100\end{array}$ & $\begin{array}{l}7,03 \\
100\end{array}$ & $\begin{array}{c}3,4952 \\
99,86\end{array}$ & $\begin{array}{c}18,428 \\
99,88\end{array}$ & $\begin{array}{l}7,0158 \\
99,80\end{array}$ \\
\hline
\end{tabular}

For the radii of inertia along the main central axes to differ by half $\left(i_{x}=2 i_{y}\right)$, the corresponding moments of inertia must differ by a factor of four, that is $I_{x}=4 I_{y}$. By substituting here the values of the moments of inertia, for a ratio of a smaller dimension to a larger one $(n=U / V)$ one can obtain the cubic equation $0,4408006 n^{3}-2,06991 n^{2}+0,2850 n+0,16666667=0$ with roots

$$
n_{1}=-0,21927617 ; n_{2}=0,38023623 ; n_{3}=4,534837 \text {. }
$$

Of these roots, the second is of practical use, the value of which can be rounded up

$$
n=0,38024=1 / 2,63
$$

and get the ratio given. 


\section{Results}

If we take the cross-sectional area as the initial data to continue the calculation calculations $A=$ const and the thickness $t=$ const of the strip (sheet billet), then with respect to the flat-oval pipes with the ratio $n=0,38024=1 / 2,63$ can be written:

$$
\begin{gathered}
U=(A / t) /(2 / n+1,14)=(A / t) /(2 / 0,30824+1,14)=0,156250(A / t) \\
V=(A / t) /(2+1,14 n)=(A / t) /(2+1,14 \times 0,30824)=0,4109352(A / t) \\
n=U / V=0,156250 / 0,4109352=1 / 2,6299852 \approx 1 / 2,63 \\
I_{x}=U^{3} t\left(0,0740286+0,785(1 / n-0,363)^{2}+(1 / n-1)^{3} / 6\right)= \\
=(0,156250(A / t))^{3} t\left(0,0740286+0,785(2,63-0,363)^{2}+(2,63-1)^{3} / 6\right) \\
=0,0184251\left(A^{3} / t^{2}\right) \\
I_{y}=U^{3} t(0,5 / n-0,1075)=(0,156250(A / t))^{3} t(0,5 \times 2,63-0,1075)=0,0046061\left(A^{3} / t^{2}\right)(12) \\
I_{x} / I_{y}=0,0184251 / 0,0046061=4,0001519 \approx 4 \\
i_{x}=\sqrt{I_{x} / A}=\sqrt{0,0184251\left(A^{3} / t^{2}\right) / A}=0,1357390(A / t) \\
i_{y}=\sqrt{I_{y} / A}=\sqrt{0,0046061\left(A^{3} / t^{2}\right) / A}=0,0678682(A / t) \\
i_{x} / i_{y}=0,1357390 / 0,0678682=2,0000383 \approx 2
\end{gathered}
$$

\section{Discussions}

To compare the new solution with the known, five variants of the steel truss of the coating of the industrial building with a span of $18 \mathrm{~m}$ from the profile pipes are considered:

- a rafter truss made of curved profiles of rectangular (square) section [10];

- a truss with a lattice of rhombic pipe [11];

- a truss with a grille made of a round tube [12];

- a truss with a lattice made of an oval pipe [12];

- a truss with a lattice of flat-oval pipes,

\begin{tabular}{|c|c|c|c|c|c|c|c|}
\hline \multirow[b]{2}{*}{$\begin{array}{c}\text { Cross sections, } \\
\mathrm{mm}\end{array}$} & \multirow{2}{*}{$\begin{array}{l}\text { Length, } \\
\text { mm * }\end{array}$} & \multirow{2}{*}{$\begin{array}{l}\text { Quantity, } \\
\text { pieces }\end{array}$} & \multicolumn{4}{|c|}{ Weight, kg } & \multirow[t]{2}{*}{ Notes } \\
\hline & & & $1 \mathrm{~m}$ & 1 piece & all & total & \\
\hline 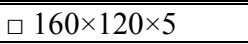 & 9000 & 2 & 20,7 & 186,3 & 372,6 & \multirow{3}{*}{$\begin{array}{l}880,4 \\
100 \%\end{array}$} & \multirow[t]{2}{*}{ Belts } \\
\hline$\square 120 \times 4$ & 7500 & 2 & 14,3 & 107,3 & 214,6 & & \\
\hline$\square 100 \times 4$ & 2390 & 8 & 11,8 & 28,2 & 225,6 & & \\
\hline
\end{tabular}

where the formation of the transition and flattened parts of the rod elements of the tube-shaped lattices is recommended to be performed with a slope of the transition section $1 / 4[13]$.

The flow rate of the structural material of the compared variants is given in Table 2, from which it can be seen that the minimum value is in the modifications of a truss with a lattice of an oval pipe (one of the known solutions) and a lattice of a flat-oval pipe (a new solution). In this case, a new solution can be given preference, since a flat-oval pipe, converted from a round tube, has a more compact cross-section $(\mathrm{mm})$ than an oval pipe $(\mathrm{mm})$, converted from a round tube of the same caliber $(\mathrm{mm})$.

Table 2. The consumption of structural material on the rod elements of the trusses 


\begin{tabular}{|c|c|c|c|c|c|c|c|}
\hline$\square 80 \times 3$ & 2390 & 4 & 7,07 & 16,9 & 67,6 & & Lattice \\
\hline $\bar{c} \square 160 \times 120 \times 5$ & 9000 & 2 & 20,7 & 186,3 & 372,6 & \multirow{3}{*}{$\begin{array}{r}851,7 \\
96,7 \%\end{array}$} & \multirow[t]{2}{*}{ Belts } \\
\hline$\square 120 \times 4$ & 7500 & 2 & 14,3 & 107,3 & 214,6 & & \\
\hline$\diamond 80 \times 4$ & 2390 & 12 & 9,22 & 22,04 & 264,5 & & Lattice \\
\hline$\square 160 \times 120 \times 5$ & 9000 & 2 & 20,7 & 186,3 & 372,6 & \multirow{3}{*}{$\begin{array}{r}831,0 \\
94,4 \%\end{array}$} & Belts \\
\hline$\square 120 \times 4$ & 7500 & 2 & 14,3 & 107,3 & 214,6 & & \\
\hline$\circ 102 \times 3,5$ & 2390 & 12 & 8,50 & 20,32 & 243,8 & & Lattice \\
\hline$\square 160 \times 120 \times 5$ & 9000 & 2 & 20,7 & 186,3 & 372,6 & \multirow[b]{3}{*}{$\begin{array}{r}799,3 \\
90,8 \%\end{array}$} & Belts \\
\hline$\square 120 \times 4$ & 7500 & 2 & 14,3 & 107,3 & 214,6 & & \\
\hline $\begin{array}{l}\text { Oval } \\
125,6 \times 52,4 \times 3,5 * * \\
(\circ 89 \times 3,5)\end{array}$ & 2390 & 12 & 7,38 & 17,64 & 212,1 & & Lattice \\
\hline 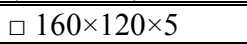 & 9000 & 2 & 20,7 & 186,3 & 372,6 & \multirow{3}{*}{$\begin{array}{r}799,3 \\
90,8 \%\end{array}$} & Belts \\
\hline$\square 120 \times 4$ & 7500 & 2 & 14,3 & 107,3 & 214,6 & & \\
\hline $\begin{array}{l}\text { Flat-oval } \\
113,5 \times 45,5 \times 3,5 * * \\
(\circ 89 \times 3,5)\end{array}$ & 2390 & 12 & 7,38 & 17,64 & 212,1 & & Lattice \\
\hline
\end{tabular}

\section{Conclusions}

Thus, the new solution allows, depending on the design requirements, a certain choice of the ratio of the dimensions of the cross-section of flat-oval pipes, and also the location of these dimensions in the axial planes of the truss structures to regulate their stress-strain states. Such regulation provides optimization of physical and mechanical properties and technical and economic characteristics of load-bearing structures of buildings and structures. In this case, it becomes possible to use the round tubes corresponding to them as caliber for the initial blanks for flat-oval profiles, which can lead to an additional positive effect. Such a regulation is not limited to the given value of $1 / 2,63(n=0,38024)$, but having a very wide range, in general, can ensure the efficiency of further optimization of load-bearing structures of buildings and structures.

\section{References}

1. Trofimov V.I., Kaminsky A.M. Light metal structures of buildings and structures. Moscow: Publishing House ASV, (2002). P. 576.

2. Marutyan A.S. Design of light steel structures from cross systems, including modules of the Pyatigorsk type. - Pyatigorsk: NCFU, (2013). P. 436.

3. Podlipsky A.A. Steel rod constructions of coatings. - Moscow: State Publishing House of Literature on Construction and Architecture, (1954). P. 147.

4. Marutyan A.S. Bearing structures with grids made of flat-oval pipes. - The patent No.2601351, 10.11.2016, the bulletin. No. 31.

5. Guide to the design of steel structures from steel bent closed welded profiles / Moscow: CRI project steel construction, (1978). P. 24, paragraph 4.2.8.

6. Pokrovsky A.A. On the account of the rigidity of nodes in the calculation of trusses with elements of small flexibility // Construction mechanics and calculation of structures, (2011). № 3. P. 31-32. 
7. Metal structures. In 3 vol. V. 1. Elements of structures / Ed. V.V. Gorev. - Moscow: Higher School, (2004). P. 332, Fig. 6.11.

8. Handbook on the resistance of materials / Ed. G.S. Pisarenko. - Kiev: Naukova Dumka, (1988). P. 68-69.

9. GOST R 54157-2010. Steel profile pipes for metal structures. Technical conditions Moscow: Standardinform, (2011). P. 62-65.

10. Kuzin N.Ya. Design and calculation of steel truss coatings for industrial buildings. Moscow: Publishing House ASV, (1998). P. 157-172.

11. Marutyan AS, Chernov P.S., Orobinskaya V.N., Galdin E.V. Improvement of Truss Bearing Capacity by Means of Rhombic Pipes // Key Engineering Materials, (2017) Trans Tech Publications, Switzerland. ISSN: 1662-9795, Vol. 736, P. 171-176.

12. Marutyan A.S., Orobinskaya V.N. Optimization of structures with lattices of round and oval pipes // Vestnik MGSU. 2016. No. 10. P. 45-57.

13. Packer J.A., Wardenier J., Zhao X.-L., G.J. van der Vegte and Kurobane Y. Construction with hollow steel sections. Design Guide for rectangular hollow section (RHS). CIDECT, (2009). P. 102. 